\title{
Uji Konsentrasi Metabolit Cendawan Endofit asal Tanaman Kacang Tanah sebagai Penghambat Pertumbuhan Aspergillus flavus
}

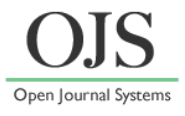

\author{
Nela Zahara, ${ }^{1, *}$, Bonny Poernomo Wahyu Soekarno ${ }^{2}$, Abdul Munif ${ }^{2}$ \\ ${ }^{1}$ Prodi Proteksi Tanaman, Universitas Bengkulu \\ ${ }^{2}$ Departemen Proteksi Tanaman, Institut Pertanian Bogor \\ *Email: nzahara@unib.ac.id \\ DOI: https://doi.org/10.33369/pendipa.5.1.63-69
}

\begin{abstract}
Peanut (Arachis hypogaea L.) is one of the important crops in Indonesia due to its nutritional content richness. Consumption of peanuts will continue to increase along with the population growth in Indonesia. However, production of peanut did not meet the national consumption needed. The low productivity was caused by several number of technical factors such as tillage, fertilization, harvesting, pest and disease control, and the use of low-quality seeds. The low quality of peanut seeds may be caused by seed-borne fungi such as Aspergillus flavus which lead to seed abortion and the change of nutritional content. The use of fungi metabolites can be used as an effective and efficient alternative control. This study was aimed to obtain endophytic fungi that have the potential as biological control agents for A. flavus. In this research, we evaluate this purpose by A. flavus and endophytic fungi isolation from peanut tissue, pathogenicity test, inhibition test against A. flavus, extraction and metabolite testing of endophytic fungi. Based on the results of the pathogenicity test, there are 33 endophytic fungi which are non-pathogenic. We select the best three isolates based on its mechanisms in inhibiting A. flavus' growth, namely CED-5, CEA-11, and CEB-2 with inhibiting rate at 51.47\%, 51.32\%, and 50.73\%, respectively. Based on macroscopic and microscopic characterization, it has shown that CED-5, CEA-11, and CEB-2 are sterile hyphae, Penicillium sp., Monascus, respectively. Evaluation of the ability of metabolites against A. flavus reveal that CEA-11, CED5 , and CEB-2 inhibit the pathogen's growth up to $40.44 \%, 39.88 \%$, and $24.71 \%$, respectively. The results showed that metabolites of endophytic fungi could be recommended in A. flavus controlling strategy.
\end{abstract}

Keywords: Aspergillus flavus; endophytic fungi, metabolites; peanut.

\begin{abstract}
ABSTRAK
Kacang tanah (Arachis hypogaea L.) merupakan salah satu tanaman pangan penting di Indonesia karena bijinya memiliki kandungan gizi. Konsumsi kacang tanah akan terus meningkat seiring dengan pertambahan jumlah penduduk di Indonesia. Meningkatnya konsumsi kacang tanah di Indonesia tidak diikuti oleh peningkatan produksinya. Penurunan produksi ini dapat disebabkan oleh beberapa faktor teknis budidaya yang kurang baik, seperti pengolahan tanah, pemupukkan, pemanenan, pengendalian hama dan penyakit serta penggunaan benih bermutu rendah. Rendahnya mutu benih kacang tanah disebabkan adanya infeksi dari cendawan benih. A. flavus yang merupakan cendawan penting yang mempengaruhi mutu benih. Penggunaan metabolit cendawan dapat dijadikan alternativ pengendalian yang efektif dan efisien. Penelitian ini bertujuan untuk mendapatkan cendawan endofit yang berpotensi sebagai agens pengendali hayati terhadap Aspergillus flavus. Tahapan penelitian terdiri atas isolasi A. flavus, isolasi cendawan endofit dari jaringan kacang tanah,uji patogenesitas, uji penghambatan terhadap A. flavus, ekstraksi dan uji metabolit cendawan endofit. Berdasarkan hasil uji patogenesitas terdapat 33 cendawan endofit nonpatogenik terhadap tumbuhan. Hasil seleksi mendapatkan 3 cendawan endofit dengan penghambatan terbaik, yaitu CED-5 (51.47\%), CEA-11 (51.32\%), dan CEB-2 (50.73\%). Identifikasi cendawan endofit berdasarkan makroskopis dan mikroskopik menunjukkan bahwa CED-5, CEA-11, dan CEB-2 berturut-turut adalah hifa Steril 1, Penicillium sp., Monascus. Memiliki daya hambat metabolit terhadap pertumbuhan A.flavus terbaik pada konsentrasi metabolit 30\% . yaitu. CEA-11 (40.44\%), CED-5(39.88\%), dan CEB-2 (24.71\%). Hasil
\end{abstract}


penelitian menunjukkan potensi metabolit dari cendawan endofit sebagai salah satu bagian strategi pengendalian A. flavus.

Kata kunci: Aspergillus flavus; cendawan endofit; kacang tanan; metabolit.

\section{PENDAHULUAN}

Benih kacang tanah membawa patogen baik dari tanaman maupun dari pascapanen. Infeksi patogen pada benih saat pascapanen dapat terjadi mulai dari lapangan, saat pengangkutan hingga penyimpanan, melalui tanah yang terbawa angin, air dan alat-alat pertanian (Semangun, 2008). Infeksi benih kacang tanah tersebut umumnya disebabkan oleh cendawan antara lain Alternaria citri, A. dianthicola, Aspergillus flavus, A. niger, A. alternata, A. carneus, A. nidulans, $A$. ocrhraceus, A. oryzae, A. tamarii, Botryodiplodia theobromae, Botrytis cineria, Cephalosporium sp., Cheetomium sp. Cladosporium sp., Colletotrichum dematium, Curvularia lunata, Deshlera sp. Fusarium oxysporum, F. semitectum, F. solani, Macrophomia phaseolina, Mucor sp., Penicillium sp., Rhizopus stolonifer, Rhizoctonia solani, Sclerotium bataticola, Stemphylium sp., Trichothecium sp., dan Verticillium sp. (Elwakil et al. 2001). Aspergillus flavus menjadi spesies yang paling dominan menginfeksi benih kacang tanah di penyimpanan (Ganjar et al. 2000).

Pakki dan Muis (2006) melaporkan bahwa infeksi A. flavus dapat menghasilkan aflatoksin pada kacang tanah yang merupakan hasil interaksi antara faktor genetik dan lingkungan. Kontaminasi aflatoksin dimulai dari infeksi di pertanaman dan terbawa benih ke tempat penyimpanan, kemudian dapat menyebabkan kerusakan di gudang-gudang penyimpanan. $A$. flavus merupakan cendawan yang bersifat saprofit yang dapat dijumpai dimana saja, seperti di tanah, di udara bebas, pada bahan-bahan makanan, dan biji, penyimpanan benih. Kacang tanah merupakan salah satu substrat yang cocok untuk pertumbuhan dan perkembangan berbagai cendawan terutama $A$.

Upaya untuk mengurangi resiko kerugian yang disebabkan A. flavus telah dilakukan berupa perlakuan benih secara kimiawi dengan aplikasi fungisida sintetik, secara fisik dengan perendaman dalam air panas dan radiasi. Meskipun demikian, masih dianggap perlu untuk mengembangkan alternatif pengendalian cendawan patogen terbawa benih yang efektif, efisien, ramah lingkungan, dan berkelanjutan. Senyawa metabolit mikrob endofit merupakan salah satu cara pengendalian cendawan terbawah benih yang potensial untuk dikembangkan.

Penelitian ini bertujuan untuk mengisolasi cendawan endofit potensial dari jaringan dan benih tanaman kacang tanah serta untuk mengetahui potensi metabolit mikrob endofit dalam menghambat cendawan patogen terbawa benih A. flavus pada kacang tanah.

\section{METODE PENELITIAN}

\section{Waktu dan Lokasi Penelitian}

Penelitian dilakukan di Laboratorium Mikologi Tumbuhan, Departemen Proteksi Tanaman, Fakultas Pertanian, Institut Pertanian Bogor.

\section{Alat dan Bahan}

Alat yang digunakan pada penelitian ini adalah mikroskop, cawan petri, tabung reaksi, centrifuge, shaker, mikropipet, vortex, objek glass, cover glass, syringe filter $0,2 \mu \mathrm{m}$. Bahan yang digunakan adalah benih kacang tanah varietas Kidang, isolat cendawan patogen $A$. flavus yang diisolasi dari benih kacang tanah, isolat mikrob endofit asal benih, akar, batang, dan daun tanaman kacang tanah, media PDA (Potatoes dextrose agar, media PDB (Potato dextrose broth), tanah steril, alkohol 70\%, NaOCl $3 \%$.

\section{Analisis Data}

Percobaan dilakukan menggunakan rancangan acak lengkap (RAL) faktorial dengan 2 faktor yang terdiri atas faktor isolat Cendawan endofit sebanyak 3 isolat dan faktor konsentrasi metabolit $(5 \%, 10 \%, 15 \%, 20 \%$, dan $30 \%)$ dan kontrol masing-masing terdiri atas 8 ulangan. Data dianalisis menggunakan program SAS 9.1. Perlakuan yang berpengaruh nyata dilakukan uji lanjut menggunakan uji selang berganda Duncan (DMRT) pada taraf 5\%. 


\section{Isolasi Aspergillus flavus}

Isolasi cendawan A. flavus dilakukan dengan metode blotter test dengan metode standart ISTA (1996). Sebanyak 3-4 helai kertas merang dilembabkan dengan menyemprotkan kertas dengan air steril. Sebanyak 10 benih kacang tanah disusun ke dalam cawan petri. Selanjutnya diinkubasi selama 7 hari. Amati karakter pertumbuhan cendawan dan gejala yang tumbuh. Cendawan patogen yang diduga $A$. flavus diisolasi kedalam medium PDA steril komposisi medium PDA terdiri dari agar, kentang, dan dekstrose. Kemudian cendawan patogen A. flavus diidentifikasi dibawah mikroskop dan di karakterisasi menggunkkan buku identifikasi Barnett et al (1998).

\section{Isolasi Cendawan Endofit}

Akar, batang, daun dan benih dari tanaman kacang tanah dicuci bersih dengan air mengalir kemudian dikeringanginkan. Masing-masing bagian tanaman kacang tanah dipotong dengan ukuran 1$2 \mathrm{~cm}$ sebanyak 5 bagian. Kemudian potongan masing-masing jaringan direndam dalam alcohol $70 \%$ selama 1 menit, $\mathrm{NaOCl} 3 \%$ selama 3 menit, dan dibilas dalam aquades steril sebanyak 3 kali, kemudian jaringan yang sudah disterilisasi dikeringkan dengan tisu steril. Bagian jaringan tanaman tersebut ditanam pada cawan petri steril yang sudah berisi media PDA dan diinkubasi pada suhu ruang selama 5-7 hari (Nur'asiah 2011).

\section{Uji Patogenesitas Cendawan Endofit}

Uji patogenisitas dilakukan dengan menyiapkan masing-masing isolat murni cendawan endofit, kemudian benih kacang tanah disterilisasi permukaan dengan mengikuti metode sterilisasi yang sudah dijelaskan sebelumnya. Sebanyak 10 benih kacang tanah di tanam pada masing-masing biakan murni cendawan endofit di dalam cawan petri dilakukan sebanyak 3 ulangan kemudian diinkubasi dalam suhu ruang. Parameter yang diamati adalah kemampuan berkecambah dan terdapat gejala nekrotik atau tidak. Apabila benih berkecambah dan tidak memiliki gejala nekrotik mengindikasikan bahwa isolat cendawan tersebut tidak bersifat patogenik terhadap tanaman.

\section{Uji Potensi Cendawan Endofit Sebagai Penghasil Senyawa Volatile}

Pengujian produksi senyawa volatil membutuhkan cawan petri yang diameternya sama antara bagian dasar dan bagian tutup. Isolat A. flavus diinokulasikan pada media PDA yang berada di bagian dasar, dan isolat cendawan endofit diinokulasikan pada media PDA yang berada di bagian tutup. Sepasang cawan tersebut direkatkan menggunakan plastik perekat. Inkubasi dilakukan pada suhu ruang selama 7 hari Prosedur pengujian produksi senyawa volatil oleh bakteri endofit sama dengan cendawan endofit. Persentase tingkat hambatan relatif terhadap $A$. flavus dihitung menggunakan rumus:

$\mathrm{DH}=((\varnothing \mathrm{k}-\varnothing \mathrm{p}) / \varnothing \mathrm{k}) \times 100 \%$

Keterangan:

$\mathrm{DH}=$ Tingkat hambatan relatif

$\varnothing \mathrm{k}=$ Diameter A. flavus pada kontrol

$\emptyset \mathrm{p}=$ Diameter A. flavus pada perlakuan.

\section{Uji Penghambatan Cendawan Endofit Terhadap} A. flavus

Isolat cendawan A. flavus yang sudah murni dan cendawan endofit yang telah diperoleh dari uji sebelumnya, kemudian diuji pada media PDA secara in vitro. Pengujian dilakukan dengan cara menumbuhkan koloni cendawan secara berpasangan yaitu dengan metode kultur ganda (Gambar 1). Selanjutnya diinkubasi pada suhu ruang selama 3-7 hari dengan 10 ulangan (Santoso \& Sumarni 2008). Tiga cendawan endofit yang memiliki nilai penghambatan tertinggi terhadap pertumbuhan cendawan patogen A. flavus yang akan digunakan pada uji selanjutnya. Perhitungan daya hambat dengan menggunakan rumus sebagai berikut:

$$
\text { Zona hambat }=\frac{\mathrm{r} 1-\mathrm{r} 2}{\mathrm{r} 1} \times 100 \%
$$

Keterangan:

$\mathrm{r} 1$ = Jarak jari-jari A. flavus yang tumbuh pada kontrol r2 = Jarak jari-jari A. flavus yang tumbuh pada perlakuan

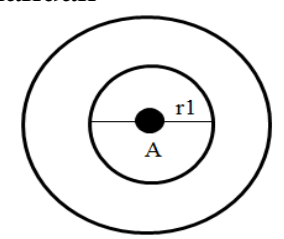

[1]

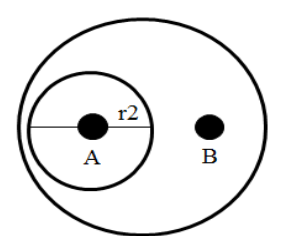

[2]
Gambar 1. Skema uji penghambatan cendawan endofit dan A. flavus. [1] A: A. flavus sebagai kontrol; [2] A: A. flavus, B: Cendawan endofit 


\section{Ekstraksi dan Uji Metabolit Cendawan Endofit Terhadap Pertumbuhan A. flavus}

Metode ekstraksi metabolit cendawan endofit dilakukan dengan menyiapkan 3 isolat cendawan endofit yang terpilih. Sebanyak 3 potong isolat murni masing-masing isolat berukuran $0.5 \mathrm{~cm}$ dimasukkan kedalam erlenmeyer berisi $100 \mathrm{~mL}$ medium PDB. Selanjutnya medium PDB tersebut digoyang menggunakan shaker dengan kecepatan 100 rpm selama 2 minggu pada suhu ruang. Kemudian medium PDB disentrifugasi dengan kecepatan $6000 \mathrm{rpm}$ selama 20 menit untuk memisahkan supernatant, dan dilakukan penyaringan metabolit dengan syringe filter $0.2 \mu \mathrm{m}$. Metode ini mengikuti Achmad (1997) yang telah dimodifikasi. Sebanyak $30 \mathrm{~mL}$ masing-masing metabolit dicampur dengan $70 \mathrm{~mL}$ media PDA yang masih cair pada suhu sekitar $50{ }^{\circ} \mathrm{C}$ (untuk pengenceran $30 \%$ ), dan dilanjutkan pengenceran $20 \%, 15 \%, 10 \%$ dan 5\%. Selanjutnya campuran PDA dengan masing-masing metabolit dituang pada cawan petri hingga padat kemudian ditumbuhkan potongan cendawan A. flavus. Pengujian untuk masing-masing konsenrasi diulang 8 kali dan diinkubasi pada suhu ruang selama 7 hari. Sebagai kontrol, potongan isolat $A$. flavus ditumbuhkan pada media PDA. Peubah yang diamati adalah diameter A. flavus pada medium PDA dengan campuran metabolit dibandingkan dengan medium PDA kontrol.

$$
\text { Daya hambat }=\frac{\mathrm{D} 1-\mathrm{D} 2}{\mathrm{D} 1} \times 100 \%
$$

Keterangan:

D1 = Diameter A. flavus pada kontrol $(\mathrm{cm})$

$\mathrm{D} 2=$ Diameter $A$. flavus pada perlakuan $(\mathrm{cm})$

\section{HASIL DAN PEMBAHASAN}

Cendawan Aspergillus flavus

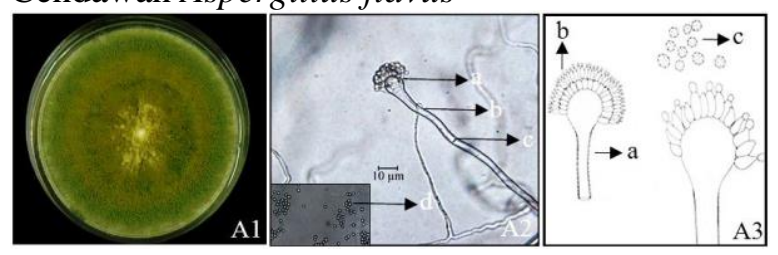

Gambar 2. (A1) Cendawan A. flavus. tampak depan; (A2) Karakteristik mikroskopis A. flavus (a) vesikel; (b) konidiofor; (c) sekat; dan (d) konidia (perbesaran 400x); (A3) Ilustrasi mikroskopis A. flavus. Menurut Gandjar et al. (2000): (a) konidiofor; (b) konidium; (c) konidia.

$\checkmark$. flavus yang diisolasi dengan metode blotter test, memiliki morfologi koloni agak kasar, berwarna kuning kehijauan, arah pertumbuhan ke samping dan ke atas. Karakteristik mikroskopiknya memiliki konidiofor hialin dan konodia berwarna hitam terlihat pada gambar 2 .

Menurut Gandjar et al. (2000) A. flavus memiliki koloni berwarna hijau kekuningan, konidiofor berwarna hialin, kasar dan dapat mencapai panjang $1 \mathrm{~mm}$. Cendawan ini memiliki vesikula yang berbentuk bulat hingga semi bulat dan fialidnya terbentuk langsung pada vesikula. Konidianya berbentuk bulat atau semi bulat berwarna hijau pucat dan berduri. Sklerotianya sering terbentuk pada koloni baru dengan ukuran bervariasi dan berwarna coklat hingga hitam. Cendawan ini menimbulkan gejala berupa munculnya miselia berwarna kuning (berkapang) pada benih dan busuk leher atau busuk mahkota pada tanaman kacang tanah (Semangun, 2008). A. flavus juga memiliki kemampuan baik dalam menghasilkan enzim. Beberapa jenis enzim yang dihasilkan adalah amilase, selulose, amiloglukosidase.

Tabel 1. Isolat cendawan endofit asal tanaman kacang tanah dan uji patogenisitas

\begin{tabular}{lc}
\hline Bagian & Jumlah \\
\hline Akar & 21 \\
Batang & 27 \\
Daun & 14 \\
Benih & 1 \\
\hline Total & 63 \\
\hline Uji Patogenesitas \\
\hline \multicolumn{2}{c}{ Patogenik } \\
\hline \multicolumn{2}{c}{30} \\
\hline
\end{tabular}

Dari tabel 1 terlihat bahwa kelimpahan cendawan endofit yang telah diisolasi bervariasi anatar bagian tanaman yang berbeda. Cendawan endofit lebih banyak ditemukan pada bagian batang dibandingakan dengan bagian lainya dari tanaman kacang tanah. Keberadaan cendawan endofit didalam jaringan tanaman sangat beragam dan jumlahnya sangat dipengaruhi oleh banyak faktor, seperti genotif tanaman, umur tanaman, tempat tumbuh tanaman, jaringan tanaman yang 
digunakan, dan teknik isolasi, dan medium yang digunakan dalam isolasi (Hallman et al, 1997).

Wani et al. (2015) menjelaskan bahwa mikrob endofit dan tanaman inangnya merupakan fenomena mutualisme yaitu aktivitas hidup mikrob di dalam jaringan tanaman tidak menggangu namun bahkan produksi berbagai senyawa kimianya dapat membantu pertumbuhan tanaman. Dan keberadaan serta jumlahnya sangat beragam didalam jaringan tanaman seperti akar, batang, daun bahkan didalam jaringan pengangkut seperti xylem (Bacon and James, 2000). Kelimpahan cendawan endofit tertinggi dari hasil isolasi yaitu dari bagian batang dan akar hal yang sama terjadi dari hasil penelitian Ramdan et al (2013) Hasil isolasi cendawan endofit dari tanaman cabai, keragaman cendawan endofit tertinggi ditemukan pada akar dan batang.

Kemampuan Cendawan Endofit dalam Menghambat pertumbuhan A. flavus

Berdasarkan hasil daya hambat cendawan endofit terhadap A. flavus pada hari ke-7 menunjukkan dari 33 isolat cendawan endofit terdapat 3 isolat yang memiliki daya hambat diatas $50 \%$ dan daya hambat senyawa volatil diatas $40 \%$ (Tabel 2). Daya hambat hasil kultur ganda cendawan endofit terhadap A.flavus pada hari ke-7 menunjukkan bahwa 3 isolat yang memiliki daya hambat $50 \%$ adalah CED-5 yaitu sebesar $51.47 \%$, diikuti CEA-11 yaitu 51.32 dan CEB-2 sebesar 50.73\% (Gambar 3 Pengujian aktivitas kultur ganda ini dilakukan sebagai langkah awal seleksi cendawan endofit. Tondok $e t$ al. (2012) menyatakan bahwa zona hambat pada uji koloni ganda terbentuk karena senyawa antifungal cendawan endofit menghambat pertumbuhan patogen, senyawa antifungal akan bekerja menghambat perkembangan patogen.

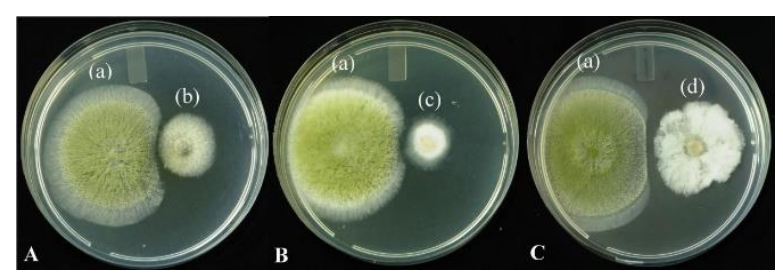

Gambar 3. Uji kultur ganda cendawan endopit terhadap $A$. flavus; A (a) Isolat cendawan A. flavus (b) Isolat cendawan endofit CED-5; B (a) Isolat cendawan A. flavus (c) Isolat cendawan endofit CEA-11; C (a) Isolat cendawan A. flavus (d) Isolat cendawan endofit CEB-2.
Tabel 2. Pengaruh cendawan endofit terhadap daya hambat pertumbuhan $A$. flavus dengan metode kultur ganda dan pengaruh senyawa volatil terhadap daya hambat $A$. flavus.

\begin{tabular}{lcc}
\hline & \multicolumn{2}{c}{ Daya hambat $(\%)$} \\
\cline { 2 - 3 } Isolat & Kultur ganda & Volatil \\
\hline CED-5 & 51.47 & 33.50 \\
CEA-11 & 51.32 & 24.23 \\
CEB-2 & 50.73 & 40.74 \\
CED-13 & 49.52 & 37.32 \\
CEB-13 & 48.65 & 36.90 \\
CEA-8 & 48.41 & 35.08 \\
CEA-24 & 47.80 & 34.26 \\
CED-14 & 47.10 & 32.82 \\
CEA-6 & 46.82 & 22.88 \\
CED-6 & 46.60 & 22.48 \\
CED-3 & 46.04 & 23.58 \\
CEA-19 & 45.97 & 33.65 \\
CEA-5 & 45.67 & 26.15 \\
CEA-12 & 45.19 & 25.10 \\
CED-12 & 45.14 & 19.10 \\
CEB-16 & 45.04 & 30.98 \\
CEB-1 & 45.00 & 36.16 \\
CEB-8 & 44.94 & 39.94 \\
CED-15 & 44.45 & 22.49 \\
CEB-22 & 44.06 & 42.95 \\
CED-4 & 44.01 & 22.04 \\
CEB-9 & 43.82 & 45.19 \\
CED-8 & 43.81 & 14.94 \\
CEB-24 & 43.77 & 30.27 \\
CEA-1 & 43.71 & 30.60 \\
CEA-9 & 43.48 & 34.78 \\
CEA-18 & 42.99 & 39.59 \\
CEA-23 & 42.90 & 26.55 \\
CEA-7 & 42.71 & 30.13 \\
CEA-22 & 42.69 & 12.71 \\
CED-10 & 41.67 & 21.68 \\
CEDH-6 & 40.49 & 22.08 \\
CEA-14 & 39.62 & 18.65 \\
KONTROL & 1.25 & 0.00 \\
\hline & & \\
& &
\end{tabular}

Pada gambar 3 terlihat bahwa patogen $A$. flavus terlihat menghindar dari cendawan endofit dan merubah arah pertumbuhannya, hal ini diduga 
ketiga cendawan endopit tersebut mengadung senyawa antimikroba. Hal ini sesuai dengan pendapat dari Prihatiningtias dan waahyuningsih (2006) bahwa zona hambat yang terbentuk pada uji patogenesitas tersebut menunjukkan bahwa adanya senyawa antimikroba yang dihasilkan dari mikrob endofit yang mampu menghambat maupun membunuh patogen.

Tondok et al. (2012) menjelaskan bahwa zona hambat (zona bening) pada uji koloni ganda terbentuk karena metabolit sekunder cendawan endofit yang terdifusi ke dalam medium agar bersifat antifungal sehingga apabila kontak langsung dengan patogen dapat menghambat pertumbuhan patogen. Ketiga isolat cendawan endofit tersebut juga menghasilkan senyawa volatil. Senyawa volatil yang dihasilkan bersifat antifungal dengan daya hambat hingga mencapai $40.74 \%$ pada isolat CEB-2. Senyawa volatil juga merupakan bagian dari metabolit sekunder yang menunjukkan mekanisme antibiosis. Keberadaan metabolit sekundar yang antifungal pada ketiga cendawan endofit membuktikan potensi ketiganya sebagai agens pengendali $A$. flavus terbawa benih kacang tanah. Khan et al. (2012) menyatakan bahwa keberadaan cendawan endofit di jaringan tanaman akan memberikan ketahanan terhadap inang dan memacu pertumbuhan tanaman karena pengaruh metabolit yang dihasilkan oleh cendawan endofit.

\section{Ekstraksi dan Uji Metabolit Cendawan Endofit Terhadap Pertumbuhan A. flavus}

Tabel 3. Pengaruh metabolit cendawan endofit terhadap pertumbuhan A. flavus pada taraf konsentrasi 5-30\%.

\begin{tabular}{cccc}
\hline $\begin{array}{c}\text { Konsentrasi } \\
\text { metabolit }(\%)\end{array}$ & \multicolumn{3}{c}{ Perlakuan } \\
\cline { 2 - 4 } & CEA-11 & CED-5 & CEB-2 \\
\hline 5 & $23.97 \mathrm{bc}$ & $18.46 \mathrm{c}$ & $20.88 \mathrm{~b}$ \\
10 & $31.18 \mathrm{~b}$ & $18.60 \mathrm{c}$ & $12.79 \mathrm{~d}$ \\
15 & $22.21 \mathrm{c}$ & $14.92 \mathrm{c}$ & $16.18 \mathrm{c}$ \\
20 & $17.06 \mathrm{c}$ & $25.09 \mathrm{~b}$ & $14.71 \mathrm{~cd}$ \\
30 & $40.44 \mathrm{a}$ & $39.88 \mathrm{a}$ & $24.71 \mathrm{a}$ \\
\hline
\end{tabular}

Angka-angka pada baris yang sama diikuti huruf yang sama tidak berbeda nyata pada taraf uji 5\% (uji selang berganda Duncan).

Gambar 4 menunjukkan metabolit cendawan endofit bersifat antifungal yang mampu menekan pertumbuhan A. flavus dan metabolit tersebut menyebabkan perubahan bentuk koloni A. flavus. Eliza et al. (2007) menyatakan bahwa senyawa antifungal yang dihasilkan oleh mikroba secara umum mengakibatkan terjadinya pertumbuhan yang abnormal pada hifa (malformasi), yaitu dengan pembengkakan dan pemendekan hifa yang mengakibatkan hifa tidak dapat berkembang dengan sempurna. Disamping itu hifa patogen dapat mengalami lisis, disebabkan karena cendawan endofit menghasilkan enzim kitinase yang dapat menyebabkan lisisnya dinding sel patogen. Aktivitas antimikrobial yang dihasilkan oleh beberapa mikrob yaitu berupa senyawa lipopeptida dan enzim pendegradasi dinding sel (Glick et al. 1999). Kelompok senyawa lipopeptida yaitu surfaktin, iturin, dan fengicin (Peypoux et al. 1999).

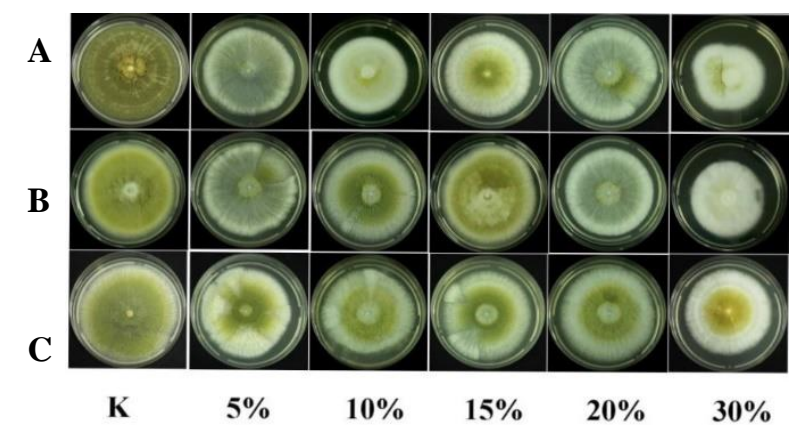

Gambar 4. Pengaruh metabolit cendawan endofit terhadap pertumbuhan A. flavus; (A) Isolat CEA-11; (B) Isolat CED5; (C) Isolat CEB-2 pada konsentrasi metabolit $5 \%, 10 \%, 15 \%, 20 \%, 30 \%$ dibandingkan kontrol $(\mathrm{K})$

\section{KESIMPULAN}

Cendawan endofit yang memiliki penghambatan terbaik terhadap A. flavus adalah CED-5 (51.47\%), CEA-11 (51.32\%), dan CEB-2 (50.73\%). CEA-11 diduga sebagai Penicillium sp., CED-5 adalah hifa steril 1, dan CEB-2 adalah Monascus sp. Perlu adanya pengujian lebih lanjut terhadap pengaruh metabolit dari cendawan endofit yang berpotensi untuk pertumbuhan dan produksi tanaman kacang tanah. Serta perlu adanya pengkajian lebih lanjut terhadap jenisjenis senyawa metabolit apa saja yang terkandung didalamnya serta konsentrasi yang tepat dalam menghambat perkembangan penyakit khususnya patogen terbawa benih yaitu A. flavus.

\section{DAFTAR PUSTAKA}

Bacon, C.W. dan James. F.W.Jr (2000) microbial endohpytes. Marcel dekker, Inc. New York. Basel [Buku]. 
Eliza, Munif A, Djatnika I, Widodo. 2007. Karakter fisiologis dan peranan antibiosis bakteri perakaran graminae terhadap Fusarium dan pemacu pertumbuhan tanaman pisang. J Hort. 17(2): 150-160.

Elwakil MA, El-Metwally MA. 2001. Seedborne fungi of peanut in egypt; pathogenicity and transmission. Pakistan Biol Sci. 4:63-68.

Gandjar I, RA Samson, KVD TweelVermeulen, A Oetari, I Santoso. 2000. Pengenalan Kapang Tropik Umum. Depok (ID). Yayasan Obor Indonesia.

Glick BR, Patten CL, Holguin G, Penrose DM. 1999. Biochemical and genetic mechanism used by plant growth promoting bacteria. $J$ Theor Biol. 190:63-68.

Hallman J, Berg G. 2006. Control of plant pathogenic fungi with bacterial endophytes. Di dalam: Schulz BJE, Boyle CJC, Sieber TN, editor. Microbial root endophytes. Jerman (EU): Springer.

ISTA [International Seed Testing Asociation]. 1996. International Rules for Seed Testing. Seed Sci Technol. 24: 39-42.

Khan SA, Hamayun M, Khan AL, Lee IJ, Shinwari ZK, Kim J. 2012. Isolation of plant growth promotic fungi from dicots inhabiting coastal sand dunes of Korea. $J$ Bot. 44(4):1453-1460.

Nur'asiah. 2011. Keanekaragaman dan kelimpahan cendawan endofit pada batang padi [skripsi]. Bogor (ID): Institut Pertanian Bogor.

Pakki S, Muis A, Talanca SH. 2006. Inventarisasi dan identifikasi cendawan yang menyerang biji jagung di Sulawesi Selatan. Maros (ID): Hasil Penelitian Hama dan Penyakit. Balitsereal. Maros. hlm:21-30.
Peypoux F, Bonmatin JM, Wallach J. 1999. Recent trends in the biochemistry of surfactin. Appl. Microbiol. Biotechnol. 51:553-563.

Prihatiningtias, W dan M. S. H. Wahyuningsih. 2006. Prospek Mikroba Endofit Sebagai Sumber Senyawa Bioaktif. Artikel Kesehatan. Universitas Gadja Mada. Yogyakarta.

Ramdan EV, Widodo, Tondok ET, Wiyono S, Hidayat SH. 2013. Cendawan endofit nonpatogen asal tanaman cabai dan potensinya sebagai agen pemacu pertumbuhan. J Fitopatol Indones. 9(5): 139-144. doi: 10.14692/jfi.9.5.139.

Santoso SJ, Sumarni. 2008. Uji antagonis mikroba filoplen terhadap Helminthosporium sorokinianum penyebab bercak daun tanaman gandum. J Inovasi Pertanian. 7(1):86-94.

Semangun, H. 2008. Penyakit-penyakit tanaman pangan di indonesia. Edisi Kedua. Gadjah Mada University Press. Yogyakarta.

Tondok ET. Sinaga MS, Widodo, Suhartono MT. 2012. Potensi cendawan endofit sebagai agens pengendali hayati Phytophthora palmivora (Butl) penyebab busuk buah kakao. J Agron Indones. 40(2): 146-152.

Wani ZA, Ashrab N, Mohiuddin T, Riyaz-UlHassan S. 2015. Plant endophyte symbiosis an ecological perspective. Applied Microbiol and Biotechnol. 99: 2955-2965. 